\title{
Arsenic redox transformation by Pseudomonas sp. HN-2 isolated from arsenic-contaminated soil in Hunan, China
}

\author{
Zhennan Zhang, Naiyi Yin, Xiaolin Cai, Zhenzhou Wang, Yanshan Cui* \\ 1. College of Resources and Environment, University of Chinese Academy of Sciences, Beijing 101408, China. E-mail: zhangzhennan10@mails.ucas.ac.cn \\ 2. Research Center for Eco-environmental Sciences, Chinese Academy of Sciences, Beijing 100085, China
}

\section{A R T I C L E I N F O}

Article history:

Received 17 September 2015

Revised 12 October 2015

Accepted 4 November 2015

Available online 8 April 2016

Keywords:

Arsenic

Arsenite oxidation

Arsenate reduction

Detoxification

Pseudomonas

\begin{abstract}
A B S T R A C T
A mesophilic, Gram-negative, arsenite[As(III)]-oxidizing and arsenate[As(V)]-reducing bacterial strain, Pseudomonas sp. HN-2, was isolated from an As-contaminated soil. Phylogenetic analysis based on 16S rRNA gene sequencing indicated that the strain was closely related to Pseudomonas stutzeri. Under aerobic conditions, this strain oxidized $92.0 \%(61.4 \mu \mathrm{mol} / \mathrm{L})$ of arsenite to arsenate within $3 \mathrm{hr}$ of incubation. Reduction of $\mathrm{As}(\mathrm{V})$ to $\mathrm{As}$ (III) occurred in anoxic conditions. Pseudomonas sp. HN-2 is among the first soil bacteria shown to be capable of both aerobic As(III) oxidation and anoxic $\mathrm{As}(\mathrm{V})$ reduction. The strain, as an efficient $\mathrm{As}$ (III) oxidizer and $\mathrm{As}(\mathrm{V})$ reducer in Pseudomonas, has the potential to impact arsenic mobility in both anoxic and aerobic environments, and has potential application in As remediation processes.

C 2016 The Research Center for Eco-Environmental Sciences, Chinese Academy of Sciences. Published by Elsevier B.V.
\end{abstract}

\section{Introduction}

Arsenic(As) is a natural and ubiquitous metalloid that ranks the 20th most abundant in the earth's crust (Cullen and Reimer, 1989). Many people around the world are exposed to As-polluted underground water and soil and suffer from chronic As poisoning, which causes hyperkeratosis, cancer, diabetes, cardiovascular disease, and other diseases (Sumi and Himeno, 2012).

Arsenic occurs in several oxidation states including arsenate $(\mathrm{As}(\mathrm{V}))$, arsenite $(\mathrm{As}(\mathrm{III}))$, elemental As (As0) and arsenide (As(-III)). Arsenic is mostly found in inorganic forms as trivalent arsenite $(\mathrm{As}(\mathrm{III}))$ or pentavalent arsenate $(\mathrm{As}(\mathrm{V}))$ (Cullen and Reimer, 1989). Among them, As(III) is generally regarded as more mobile and more toxic than $\mathrm{As}(\mathrm{V})$ (Liu et al., 2001). The affinity of $\mathrm{As}(\mathrm{III})$ for protein thiols or vicinal sulfhydryl groups makes it highly toxic. As(III) also acts as an endocrine disruptor by binding to hormone receptors and interfering with normal cell signaling (Kaltreider et al., 2001). $\mathrm{As}(\mathrm{V})$ is a chemical analog of phosphate with subsequent inhibition of oxidative phosphorylation (Goyer and Clarkson, 1996).

The contribution made by microorganisms to the biogeochemistry of As in the environment is extensive and detailed. Microbial activity strongly influences As speciation. Various bacteria are known for their ability to transform inorganic As species through oxidation or reduction processes (Jones et al., 2012; Oremland and Stolz, 2003). For chemoautotrophic As(III) oxidizers, the oxidation of As(III) generates energy, which promotes their growth and proliferation (Santini et al., 2000); whereas for heterotrophic As(III) oxidizers, the oxidation of As(III) is described as a detoxification mechanism catalyzed

\footnotetext{
* Corresponding author. E-mails: zhangzhennan10@mails.ucas.ac.cn (Zhennan Zhang), cuiyanshan@ucas.ac.cn (Yanshan Cui).
} 
by the periplasmic enzyme arsenite oxidase (Muller et al., 2003). Dissimilatory arsenate-reducing prokaryotes conserve energy by linking the oxidation of lactate to the reduction of $\mathrm{As}(\mathrm{V})$ to As(III). Reduction of As is also carried out by resistant microbes utilizing an As(V)-reductase and As(III)-expulsion pump (Tsai et al., 2009). Biotic arsenic transformation could cause either arsenic release or immobilization in soil. It was found that bacterial activity was responsible for the reduction of arsenic, causing the solubilization of the metalloid from pyrite cinders to the aqueous phase (Corsini et al., 2010). Oxidation of $\mathrm{As}(\mathrm{III})$ to $\mathrm{As}(\mathrm{V})$ contributes to improved immobilization of As and thus helps to mitigate As contamination (Sun et al., 2010).

In order to better understand the mechanism of biotic As transformation in the environment and further understand the combined effect of abiotic (e.g., mineral oxidants and humus) and biotic factors on As transformation in soil, isolation of As-transformation bacteria is necessary. Furthermore, the microbial transformation of $\mathrm{As}(\mathrm{III})$ to $\mathrm{As}(\mathrm{V})$ might represent an eco-friendly, cost-effective alternative approach to conventional remediation processes (Bahar et al., 2012). Several bacterial strains have been isolated and identified as As(III) oxidizers since the first arsenite-oxidizing bacterium was described in 1918 (Green, 1918), including Stenotrophomonas (Bahar et al., 2012), Polaromonas (Osborne et al., 2010), Bacillus (Shivaji et al., 2005), Alcaligenes (Osborne and Ehrlich, 1976), Agarobacterium (Salmassi et al., 2002), Thiomonas (Bruneel et al., 2003), Microbacterium lacticum (Mokashi and Paknikar, 2002) and Bosea (Liao et al., 2011). Dissimilatory reduction of $\mathrm{As}(\mathrm{V})$ has been shown to occur in at least nine different genera scattered throughout the domain Bacteria and has also been observed in two hyperthermophilic Archaea (Macur et al., 2004). The As(V)-reducing bacteria utilizing a detoxification or resistance mechanism have also been identified and classified as Pseudomonas, Psychrobacter, Vibrio, Citrobacter, Enterobacter, Bacillus (Liao et al., 2011), Alcaligenes (Cavalca et al., 2013), Pantoea (Wu et al., 2013), Agrobacterium, Flavobacterium and Microbacterium (Macur et al., 2004). These bacteria have been generally isolated from soils (Bahar et al., 2012; Majumder et al., 2013), groundwater (Liao et al., 2011; Mokashi and Paknikar, 2002), Hot Creek (Salmassi et al., 2002), mines (Santini et al., 2000), the Arctic Circle (Osborne et al., 2010), sediments (Valenzuela et al., 2009) and plant effluents (Bachate et al., 2013). Although various kinds of As-transformation bacteria have been found, the expression by a single organism of both reductive and oxidative metabolic functions, has, to our knowledge, only been observed so far in members of Thermus, Bacillus, Marinobacter, Comamonas, Flavobacterium, Staphylococcus, and Pseudomonas genera (Fisher and Hollibaugh, 2008; Gihring and Banfield, 2001; Handley et al., 2009). These bacteria mentioned above were isolated from hot springs, lakes, marine hydrothermal sediments and plants. No soil bacterial strain with both As(III)- oxidizing and As(V)-reducing ability has been reported before.

In this article, we presented (i) the isolation of a strain with the ability of both heterotrophic As(III)-oxidation and $\mathrm{As}(\mathrm{V})$-reduction from an As-contaminated soil, (ii) phylogenetic analysis of the strain, (iii) the identification and characterization of arsenite oxidase and arsenate reductase genes, (iv)As oxidation and reduction assays.

\section{Materials and methods}

\subsection{Isolation and growth of As-resistant bacteria}

A soil sample $([\mathrm{As}]=284 \mathrm{mg} / \mathrm{kg}$ ) collected from a mine in Zhuzhou, Hunan, China, was used as an inoculum for enrichment culture. The isolation and subsequent growth experiments were carried out with a modified chemically defined medium (CDM) (8.12 mmol/L $\quad \mathrm{MgSO}_{4}, 18.7 \mathrm{mmol} / \mathrm{L} \quad \mathrm{NH}_{4} \mathrm{Cl}$, $7 \mathrm{mmol} / \mathrm{L} \mathrm{Na}_{2} \mathrm{SO}_{4}, 0.0574 \mathrm{mmol} / \mathrm{L} \mathrm{K}_{2} \mathrm{HPO}_{4}, 0.457 \mathrm{mmol} / \mathrm{L} \mathrm{CaCl}$, $44.6 \mathrm{mmol} / \mathrm{L} \mathrm{Na}$-lactate and $9.5 \mathrm{mmol} / \mathrm{L} \mathrm{NaHCO}_{3}$, with the $\mathrm{pH}$ adjusted to 7.0) as described by Weeger et al. (1999). As-resistant bacteria were enriched with $1.33 \mathrm{mmol} / \mathrm{L}$ As(III) under oxic incubation. $1 \mathrm{~g}$ soil samples were placed in sterile flasks containing CDM supplemented with $1.33 \mathrm{mmol} / \mathrm{L} \mathrm{As(III),} \mathrm{and}$ incubated at $25^{\circ} \mathrm{C}$ on a rotary shaker $(170 \mathrm{r} / \mathrm{min})$ in the dark for $48 \mathrm{hr}$. After incubation, samples were serially diluted, and a cell suspension was spread onto CDM plates with $1.33 \mathrm{mmol} / \mathrm{L}$ As(III) at $25^{\circ} \mathrm{C}$ for $48 \mathrm{hr}$ to obtain single colonies. A pure culture was obtained by successive isolation of colonies at $25^{\circ} \mathrm{C}$ in As(III)-supplemented medium.

\subsection{Selection of as(III)-oxidizing strain}

The ability of the obtained As-resistant bacteria to oxidize As(III) was tested using a qualitative $\mathrm{AgNO}_{3}$ screening method as described by Liao et al. (2011). Briefly, exponential-phase culture was centrifuged and then resuspended in CDM containing $1 \mathrm{mmol} / \mathrm{L} \mathrm{As(III).} \mathrm{The} \mathrm{bacterial} \mathrm{suspensions} \mathrm{were}$ incubated at $30^{\circ} \mathrm{C}$ for $72 \mathrm{hr}$. Subsequently, the bacterial cultures were centrifuged, and $100 \mu \mathrm{L}$ of the liquid phase was mixed with $100 \mu \mathrm{L}$ of $0.1 \mathrm{~mol} / \mathrm{L} \mathrm{AgNO}_{3}$ solution. The resulting precipitates containing As showed colors ranging from the light yellow of $\mathrm{Ag}_{3} \mathrm{AsO}_{3}$ (silver orthoarsenite) due to $\mathrm{As}$ (III) to the light brown-red of $\mathrm{Ag}_{3} \mathrm{AsO}_{4}$ (silver orthoarsenate) due to $\mathrm{As}(\mathrm{V})$. The observation of a light brown-red precipitate was regarded as indicating an As(III)-oxidizing strain. After confirmation of a pure As(III)-oxidizing strain, bacteria were preserved in $30 \%$ glycerol at $-80^{\circ} \mathrm{C}$.

\subsection{Bacterial As(III) oxidation experiment}

The ability of the bacterial isolate to oxidize As(III) was further quantitatively determined by batch tests. The cells were grown in CDM. Once the cells reached the exponential phase, they were harvested by centrifugation at $5000 \mathrm{r} / \mathrm{min}$ for $20 \mathrm{~min}$ at $4^{\circ} \mathrm{C}$ and cell pellets were resuspended in the required volume of $\mathrm{CDM}$ to obtain a cell density of about $10^{7} \mathrm{CFU} / \mathrm{mL}$. The test medium was supplemented with $5 \mathrm{mg} / \mathrm{L}$ $(66.7 \mu \mathrm{mol} / \mathrm{L})$ of $\mathrm{As}(\mathrm{III})$ and incubated on a rotary shaker $\left(150 \mathrm{r} / \mathrm{min}\right.$ ) at $30^{\circ} \mathrm{C}$. The $\mathrm{pH}$ value of the medium was adjusted to 7.0. Controls without inoculation were also incubated under the same conditions. Samples were taken over time for measurement of cell density and for determination of As speciation. Samples were centrifuged, decanted and stored at $-20^{\circ} \mathrm{C}$ prior to As analyses. Dissolved oxygen (DO), oxidation reduction potential (ORP) and $\mathrm{pH}$ were also monitored. All experiments were done in triplicate, and the mean values were taken into account. 


\subsection{Effect of pH on As(III) oxidation}

The effect of $\mathrm{pH}$ on bacterial oxidation of As(III) was assessed following the same procedure used in the batch oxidation experiment. The $\mathrm{pH}$ values of the culture medium were adjusted to 4, 5, 6, 7, 8, 9 and 10 with predetermined amounts of filter-sterilized $\mathrm{NaOH}(1 \mathrm{mmol} / \mathrm{L})$ and $\mathrm{HCl}(1 \mathrm{mmol} / \mathrm{L})$. Samples were taken over time to determine the As(III) and As(V) concentrations as well as the bacterial growth in terms of optical density (600 $\mathrm{nm}$ ).

\subsection{Bacterial As(V) reduction experiment}

A batch test was also done to determine the $\mathrm{As}(\mathrm{V})$ reduction ability of Pseudomonas sp. HN-2. The test medium was initially supplemented with $5 \mathrm{mg} / \mathrm{L}$ of $\mathrm{As}(\mathrm{V})$ under the same conditions as in Section 2.4 .

To test the strain for its ability to grow by arsenate respiration, anaerobic growth experiments were conducted. The basal growth medium for anaerobic culturing was a CDM that consisted of resazarin dye $(1 \mathrm{mg} / \mathrm{L})$ and cysteine- $\mathrm{HCl}$ ( $1 \mathrm{mmol} / \mathrm{L})$. The medium was first boiled for $30 \mathrm{~min}$, then cooled on ice while purging with $\mathrm{N}_{2}$, and then autoclaved. After autoclaving, cysteine- $\mathrm{HCl}$ was added separately from sterile anaerobic stock solutions. Three sets of anaerobic experiments were carried out in serum bottles: (i) inoculated medium containing $5 \mathrm{mg} / \mathrm{L} \mathrm{As}(\mathrm{V})$, (ii) inoculated medium with no As added, and (iii) non-inoculated controls containing $5 \mathrm{mg} / \mathrm{L} \mathrm{As}(\mathrm{V})$ (three replicates). The cell density was $10^{7} \mathrm{CFU} / \mathrm{mL}$ at the beginning. The experiments were incubated at $30^{\circ} \mathrm{C}$.

\subsection{Effect of As(III) on bacterial growth}

The effect of As(III) on growth of the bacterium was evaluated to determine the strain's tolerance to As(III) using $48 \mathrm{hr}$ growth-inhibition bioassays. Chemically defined medium containing As(III) (0.5-20 mmol/L) was inoculated with cell suspensions to a final density of $10^{7}$ cells $/ \mathrm{ml}$. A no-As(III) medium was served as the control. The $50 \%$ effective concentration $\left(E_{50}\right)$ was defined as the initial As(III) concentration resulting in a $50 \%$ decrease in growth when compared with no-As(III) control culture (Bahar et al., 2012). It was determined by applying a non-linear regression model with a Four Parameter Logistic Curve, using the software SigmaPlot (Version10.0). The minimum inhibitory concentration (MIC) represented the lowest concentration that completely inhibited the growth.

\subsection{Analysis methods}

Total As (As(III) + As(V)) concentration was determined using inductively coupled plasma optical emission spectroscopy (ICP-OES) (OPTIMA 8300, USA). Prior to the analysis, the aqueous samples were acidified with concentrated $\mathrm{HCl}$, and stored in acid-washed glass vessels. Selective As(III) analysis was performed using hydride generation-atomic fluorescence spectroscopy (HG-AFS) (Haiguang, China) (Shi et al., 2003). $1 \mathrm{~mL}$ of the test sample was transferred into a $10 \mathrm{~mL}$ test tube and $2 \mathrm{~mL}$ of $0.5 \mathrm{~mol} / \mathrm{L}$ citric acid solution was added. The solution was diluted to $10 \mathrm{~mL}$ with deionized water and then was analyzed. Citric acid $(0.1 \mathrm{~mol} / \mathrm{L})$ was used as the carrying fluid (Zhang et al., 2007).
Cell densities were determined by measuring the optical density at $600 \mathrm{~nm}$ using a UV/VIS spectrophotometer (UNICO, China). DO and $\mathrm{pH}$ were measured using a portable Hach (Sens-Ion) Multi meter (USA); ORP was measured using a portable ORP meter (METTLER TOLEDO SG, China).

\subsection{Scanning electronic microscopy analysis}

The isolated As(III)-oxidizing bacteria was investigated by scanning electronic microscopy (SEM). Exponential-phase culture was centrifuged and fixed with $2.5 \%$ glutaraldehyde in $4^{\circ} \mathrm{C}$. Then, cells were washed with phosphate buffer three times. Samples were dehydrated with alcohol, and dried with liquid $\mathrm{CO}_{2}$ using the critical point method. Finally, samples were gold coated in a sputter coater and examined in the SEM (FEI Quanta 200, Czech).

\subsection{PCR amplification of $16 \mathrm{~S}$ rDNA, aroA gene and arsC gene}

Bacterial genomic DNA was extracted using TIANamp Bacteria DNA Kit (TIANGEN, China) following the manufacturer's instructions. DNA was dissolved in Tris-EDTA buffer and stored at $-20^{\circ} \mathrm{C}$ until use. The extracted DNA was used in PCR amplification as DNA template. The PCR amplification was carried out in a $50 \mu \mathrm{L}$ PCR mixture. The mixture contained $5 \mu \mathrm{L}$ $10 \times$ PCR buffer, $4 \mu \mathrm{L}$ dNTP (1.5 mmol/L, final concentration), $1 \mu \mathrm{L}$ of each primer ( $0.4 \mathrm{mmol} / \mathrm{L}$, final concentration), $0.2 \mu \mathrm{L}$ BSA (10 mg/mL), $2 \mu \mathrm{L}$ template DNA, $0.4 \mu \mathrm{L}$ Taq DNA polymerase ( $5 \mathrm{U} / \mu \mathrm{L}$, Takara, China) and addition of RNase free $\mathrm{ddH}_{2} \mathrm{O}$ (Takara, China) to a final volume of $50 \mu \mathrm{L}$. Universal eubacterial primers (27F:5'-AGAGTTTGATCCTGGCTCAG-3';1492R:5'-GGYT ACCTTGTTACGACTT-3') (Lane, 1991) targeting 16S rRNA gene and primers (F:5'-GTSGGBTGYGGMTAYCABGYCTA-3'; R:5'-TTG TASGCBGGNCGRTTRTGRAT-3') targeting aroA gene (Inskeep et al., 2007) were used for PCR. The occurrence of arsenate reductase gene ars $C$ in the isolated strain was investigated using five reported primers (Bachate et al., 2009; Chang et al., 2008; Macur et al., 2004; Macy et al., 2000; Sun et al., 2004). The PCR products were checked using $1.0 \%$ agarose gel electrophoresis and sequenced.

\subsection{Phylogenetic analysis}

The initial sequences were searched against the GenBank database by using BLASTn (for $16 \mathrm{~s}$ rDNA) and BLASTx (for aroA gene). Phylogenetic analysis was carried out with MEGA 5.0 using a neighbor-joining method (Tamura et al., 2007).

\subsection{GenBank accession numbers}

The nucleotide sequences of $16 \mathrm{~S}$ rDNA and aroA gene of Pseudomonas sp. HN-2 have been deposited in GenBank under the accession numbers KJ452338 and KJ452340.

\section{Results}

\subsection{Isolation and morphology of Pseudomonas sp. HN-2}

Eight indigenous bacteria strains were isolated from the As-contaminated soil (data not shown), among which one 
strain capable of $\mathrm{As}(\mathrm{III})$ oxidation was isolated, and its oxidizing ability was evaluated in additional experiments. Cells of strain $\mathrm{HN}-2$ were rods, $1-1.4 \mu \mathrm{m}$ in length and $0.5-0.6 \mu \mathrm{m}$ in diameter (Fig. 1). The strain was characterized as aerobic and gram-negative.

\subsection{Phylogenetic identification}

BLAST and similarity analysis of the near full length 16S rRNA gene sequences (1465 bp) of strain $\mathrm{HN}-2$ showed that it belonged to Pseudomonas genera and was most similar to Pseudomonas stutzeri, with sequence similarities of $99.2 \%$. The phylogenetic relationships among the non-As(III)-oxidizing bacteria of Pseudomonas and selected representatives of $\mathrm{As}(\mathrm{III})$-oxidizing bacteria and $\mathrm{As}(\mathrm{V})$-reducing bacteria within $\alpha-, \beta-\gamma$-Proteobacteria and Firmicutes are shown in Fig. 2 . The As(III)-oxidizing bacteria and As(V)-reducing bacteria are phylogenetically diverse. Pseudomonas sp. $\mathrm{HN}-2$ had more than $98 \%$ 16 s rDNA sequence identity with $P$. stutzeri, suggesting it may be a strain of the same species. Both As(III)-oxidizers and As(V)-reducers have been found in Pseudomonas.

\subsection{Sequencing and characterization of arsenite oxidase gene aro $A$ and arsenate reductase gene ars $C$}

Fragments $(500 \mathrm{bp}$ ) of the aro $\mathrm{A}$ gene (synonymous with aoxB and asoA) that encode the Mo-pterin subunit of arsenite oxidase were amplified from the genomic DNA of Pseudomonas sp. HN-2. Nucleotide sequences of the PCR product obtained from the strain were translated and the deduced amino acid sequences (164 aa) showed clear homology to the arsenite oxidase large subunit from different organisms. Alignment with different proteins showed the highest identity (100\%) with the arsenite oxidase large subunit from $P$. stutzeri (Genebank accession no. WP_003291052.1).

Although growth studies confirmed the strain as an $\mathrm{As}(\mathrm{V})$ reducing bacterium, amplification of arsenate reductase gene

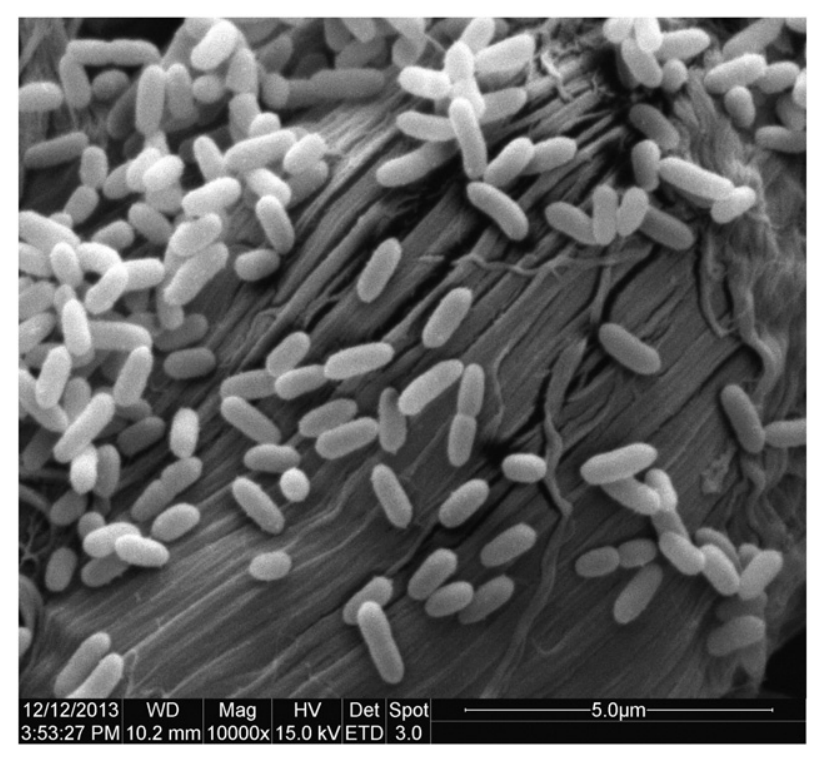

Fig. 1 - Electron micrographs of strain HN-2 grown in CDM. CDM: chemically defined medium.
arsC was not successful using a range of primers and PCR conditions.

\subsection{As(III) oxidation by the isolated strain in batch experiments and the effect of $\mathrm{pH}$}

Strain $\mathrm{HN}-2$ was able to grow in CDM, containing $5 \mathrm{mg} / \mathrm{L}$ As(III), by oxidizing As(III). The optimum $\mathrm{pH}$ and temperature for the isolate growth were found to be 7 and $30^{\circ} \mathrm{C}$. In aerobic conditions, with initial cell density of $10^{7} \mathrm{CFU} / \mathrm{mL}$, strain $\mathrm{HN}-2$ was able to oxidize $92.0 \%(61.4 \mu \mathrm{mol} / \mathrm{L})$ of $\mathrm{As}(\mathrm{III})$ to $\mathrm{As}(\mathrm{V})$ (Fig. 3). However, after $5 \mathrm{hr}$ of incubation, reduction of $\mathrm{As}(\mathrm{V})$ to As(III) was observed. It was suspected to be caused by the decline of dissolved oxygen (Table 1), which might be expended by the microorganisms.

No growth was observed when cells were cultured with As(III) as a sole energy source and growth was not enhanced in the presence of arsenic, indicating that the strain is a heterotrophic oxidizer (data not shown). No oxidation of As(III) was observed in sterile controls, indicating that As(III) oxidation required the presence of microbial cells.

Optimum growth of the strain occurred at $\mathrm{pH}$ between 6 and 9. Transformation of $\mathrm{As}(\mathrm{III})$ to $\mathrm{As}(\mathrm{V})$ was $86.0 \%, 59.6 \%, 34.1 \%$ at $\mathrm{pH} 6,8,9$, respectively. No growth or oxidation of As(III) was observed at $\mathrm{pH} 4,5$ and 10 even after $72 \mathrm{hr}$ of incubation.

\subsection{Arsenate reduction by strain $\mathrm{HN}-2$}

The reduction ability of HN-2 was also tested under aerobic and anoxic conditions. During the first $5 \mathrm{hr}$, microbes grew rapidly, but the concentration of $\mathrm{As}(\mathrm{V})$ remained relatively steady. After $5 \mathrm{hr}$ of incubation, dissolved oxygen fell to around $2 \mathrm{mg} / \mathrm{L}$ (Table 1), and reduction took place (Fig. 4). After $10 \mathrm{hr}$ incubation, dissolved oxygen dropped below $1 \mathrm{mg} / \mathrm{L}$, thus creating an anoxic environment. Transformation of $\mathrm{As}(\mathrm{V})$ to As(III) by HN-2 was $94.4 \%(63.0 \mu \mathrm{mol} / \mathrm{L})$ within $96 \mathrm{hr}$. The As(V) reduction rate was $36.5 \%$ at $24 \mathrm{hr}$.

No growth of the strain was observed when cultured with $\mathrm{As}(\mathrm{V})$ as the sole electron acceptor under anaerobic conditions. Therefore, strain HN-2 cannot grow by arsenate respiration.

\subsection{Effect of As(III) on bacterial growth}

The strain HN-2 was exposed to different concentrations of As(III) in CDM and the growth in terms of cell density $\left(\mathrm{OD}_{600}\right)$ was measured at different time intervals. A decrease in growth was observed with increasing As(III) concentration at any given time interval compared to the control (Fig. 5). There was $65.5 \%$, $42.8 \%$ and $22.5 \%$ decrease over control in the growth of the strain at $48 \mathrm{hr}$ incubation with 6,7 and $8 \mathrm{mmol} / \mathrm{L} \mathrm{As(III),}$ respectively. At 9, 10 and $12 \mathrm{mmol} / \mathrm{L}$ concentration of $\mathrm{As}(\mathrm{III})$, although little growth was observed initially, growth appeared after $48 \mathrm{hr}$ of incubation. This could be due to the very high toxicity at higher concentrations, requiring an adaptive phase in the initial hours, and subsequently entering a growth phase after $48 \mathrm{hr}$. No growth was observed at $14 \mathrm{mmol} / \mathrm{L}$ concentration of As(III). Thus, the MIC would lie between 12 and $14 \mathrm{mmol} / \mathrm{L}$. The isolate $\mathrm{HN}-2$ was found to be tolerant to As(III) with a $48 \mathrm{hr} \mathrm{EC}_{50}$ value of $7.134 \pm 0.249 \mathrm{mmol} / \mathrm{L}(99 \%$ confidence limits). 
A $\mathrm{As}(\mathrm{V})$-reducing bacteria

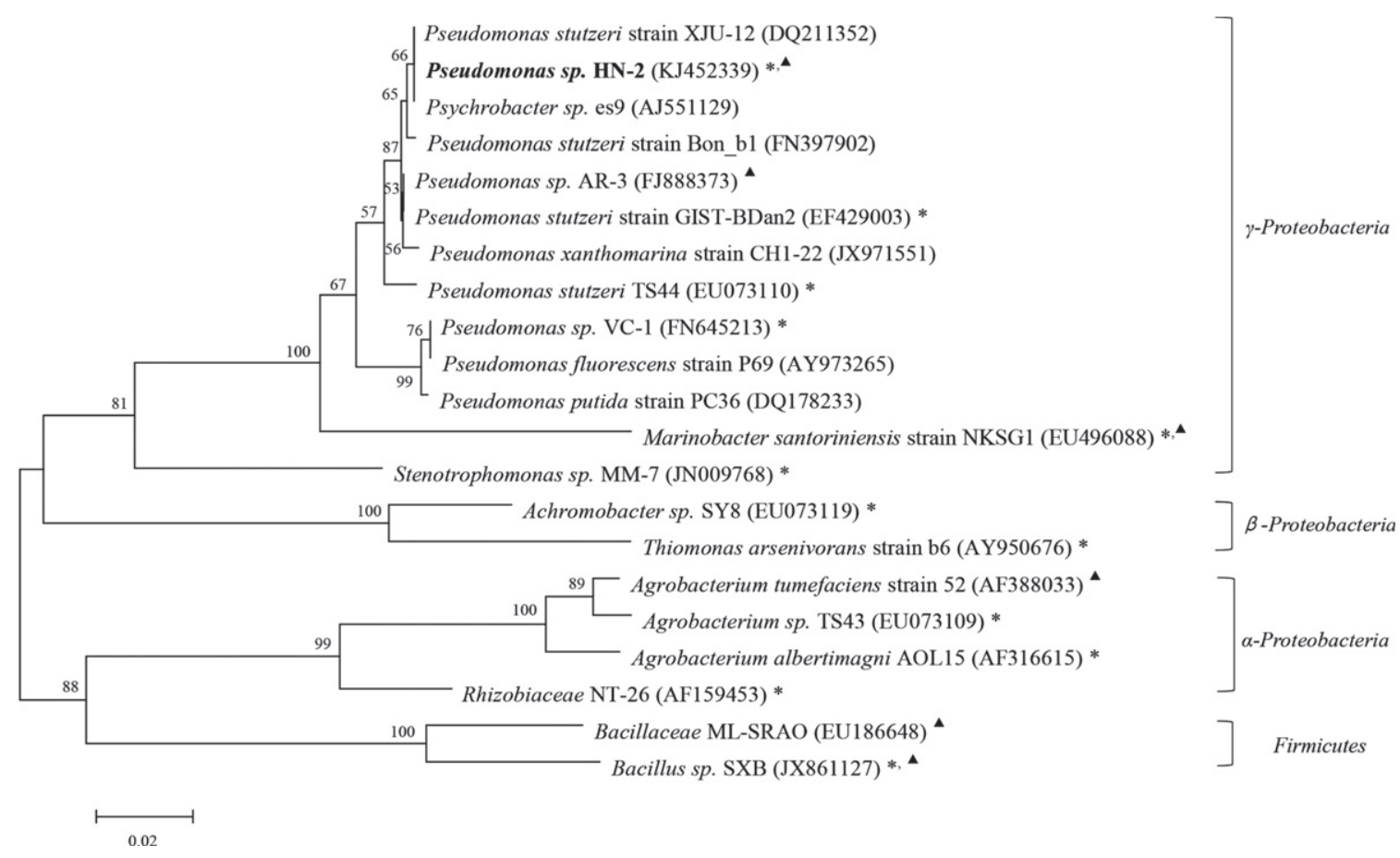

Fig. 2 - Neighbor-joining tree showing the phylogenetic relationship of the isolated strain HN-2 compared with species of non-As(III)-oxidizing bacteria of Pseudomonas, As(III)-oxidizers and As(V)-reducers of Pseudomonas isolated so far and other main As(III)-oxidizing bacteria and As(V)-reducing bacteria within $\alpha-, \beta-, \gamma$-Proteobacteria and Firmicutes (the scale bar represents 2 nucleotide substitution per 100 nucleotides of 16S rDNA sequence.

\section{Discussion}

Microbial oxidation of toxic As(III) is indispensable in biogeochemical cycling of As and has a great potential as a preoxidation strategy in the treatment process of As-contaminated water and soil. Abiotic reactions are comparatively slow and may

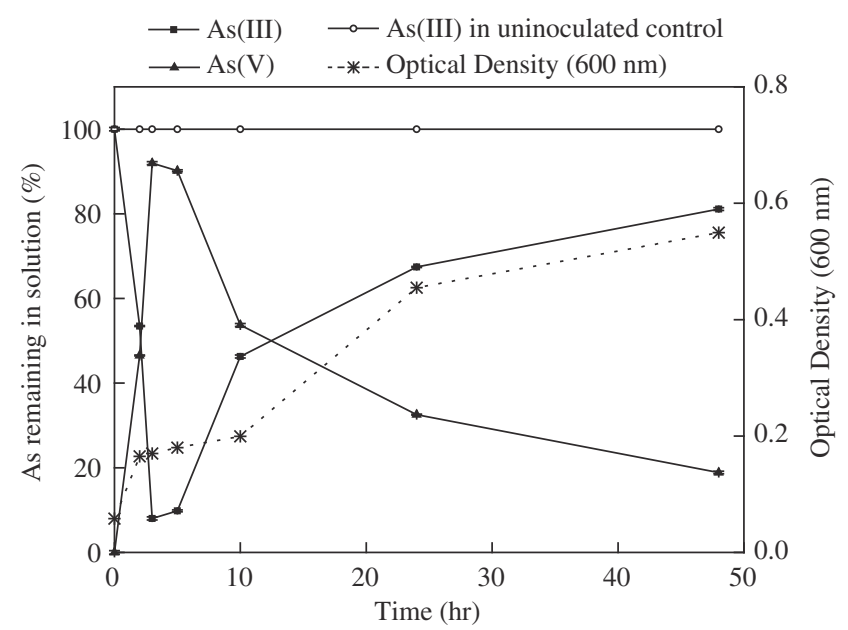

Fig. 3 - Growth (expressed as $\mathrm{OD}_{600}$ ) and $\mathrm{As}(\mathrm{III})$ oxidation by strain $\mathrm{HN}-2$ in CDM containing $5 \mathrm{mg} / \mathrm{L} \mathrm{As(III).} \mathrm{CDM:}$ chemically defined medium; As: arsenic. take months or years to reach equilibrium (Cherry et al., 1979). As(III)-oxidizing bacteria are widely distributed in the environment. Some strains can be tolerant to extreme environments, such as Polaromonas GM1 isolated from the Arctic Circle (Osborne et al., 2010) and Thermus spp. isolated from a hot spring (Gihring et al., 2001). The ability of both As(III) oxidation and As(V) reduction has been shown for a thermophilic terrestrial hot spring bacterium, Thermus HR13 (Gihring and Banfield, 2001), halophilic Mono Lake bacterium, strain Bacillus sp. ML-SRAO (Fisher and Hollibaugh, 2008) and mesophilic hydrothermal marine bacterium Marinobacter santoriniensis NKSG1 (Handley et al., 2009). Thermus HR13 was isolated aerobically, while NKSG1 and ML-SRAO were isolated anaerobically or from reducing enrichment cultures. In this study, the results illustrate the capacity of an isolated soil bacterium, Pseudomonas sp. HN-2, to undertake both $\mathrm{As}$ (III) oxidization and $\mathrm{As}(\mathrm{V})$ reduction.

Pseudomonas is broadly represented among As-resistant bacterial strains isolated from other As-contaminated sites (Anderson and Cook, 2004). Both As(III) oxidizers and As(V) reducers in Pseudomonas have been isolated before. P. stutzeri GIST-BDan2 (EF429003) is an As(III)-oxidizing strain isolated from constructed wetlands (Chang et al., 2010). Three arsenate reducers of Pseudomonas were isolated in As-rich groundwater (Liao et al., 2011). Pseudomonas sp. C-4 (Wang et al., 2012) was found to have dual capacity, but only $70 \%$ of As(III) was oxidized and $1.6 \%$ of $\mathrm{As}(\mathrm{V})$ was reduced. With its dual capacity, strain $\mathrm{HN}-2$ in this study is more efficient than Pseudomonas sp. C-4 in both As(III) oxidation and As(V) reduction. 
Table 1 - Dissolved oxygen (DO), oxidation reduction potential(ORP) and pH of samples taken at different time intervals

\begin{tabular}{|c|c|c|c|c|c|c|c|c|c|c|c|c|c|c|c|c|c|c|}
\hline \multirow[t]{2}{*}{ Time(hr) } & \multicolumn{3}{|c|}{0} & \multicolumn{3}{|c|}{2} & \multicolumn{3}{|c|}{5} & \multicolumn{3}{|c|}{10} & \multirow[b]{2}{*}{ DO } & \multirow[b]{2}{*}{ ORP } & \multirow{2}{*}{$\frac{24}{\mathrm{pH}}$} & \multicolumn{3}{|c|}{48} \\
\hline & $\begin{array}{c}\mathrm{DO} \\
(\mathrm{mg} / \mathrm{L})\end{array}$ & $\begin{array}{l}\text { ORP } \\
(\mathrm{mV})\end{array}$ & $\mathrm{pH}$ & DO & ORP & $\mathrm{pH}$ & DO & ORP & $\mathrm{pH}$ & DO & ORP & $\mathrm{pH}$ & & & & DO & ORP & $\mathrm{pH}$ \\
\hline $\mathrm{OE}^{\mathrm{b}}$ & 7.94 & -52 & 7.5 & 4.38 & -57 & 7.2 & 3.39 & -60 & 7.2 & 0.81 & -72 & 7.3 & 0.81 & -47 & 7.7 & 0.45 & -44 & 8.0 \\
\hline $\mathrm{RE}^{\mathrm{c}}$ & 7.93 & -52 & 7.5 & 4.45 & -57 & 7.2 & 2.56 & -60 & 7.2 & 0.92 & -72 & 7.3 & 0.54 & -47 & 7.7 & 0.64 & -47 & 8.0 \\
\hline $\begin{array}{l}\text { a Values ir } \\
\text { b "OE" star } \\
\text { c "RE" stan }\end{array}$ & $\begin{array}{l}\text { he table } \\
\text { for "ox } \\
\text { for "red }\end{array}$ & $\begin{array}{l}\text { e mea } \\
\text { ation } \\
\text { ction }\end{array}$ & orix & $\begin{array}{l}\text { of th. } \\
\text { nt". } \\
\text { nt. }\end{array}$ & e sam & ngs & & & & & & & & & & & & \\
\hline
\end{tabular}

Previous studies reported some highly efficient As(III) oxidizers: Agrobacterium albertimagni AOL15 completely oxidized $585 \mu \mathrm{mol} / \mathrm{L}$ As(III) within $24 \mathrm{hr}(24.38 \mu \mathrm{mol} /(\mathrm{L} \cdot \mathrm{hr}))$ with initial cell density of $10^{6}-10^{7} \mathrm{CFU} / \mathrm{mL}$ (Salmassi et al., 2002); Bacillus megaterium AMO-10 oxidized $30 \mathrm{mmol} / \mathrm{L}$ of As(III) within $24 \mathrm{hr}(1.25 \mathrm{mmol} /(\mathrm{L} \cdot \mathrm{hr}))$ (Majumder et al., 2013); Stenotrophomonas sp. MM-7 oxidized $500 \mu \mathrm{mol} / \mathrm{L}$ As(III) within $12 \mathrm{hr}(41.67 \mu \mathrm{mol} /(\mathrm{L} \cdot \mathrm{hr}))$ with initial cell density of $10^{6}$ $10^{7} \mathrm{CFU} / \mathrm{mL}$ (Bahar et al., 2012). However, some isolated strains tend to be low efficiency oxidizers, or even unable to completely oxidize As(III): Bacillus sp. AGH-02, AGO-S5, ADP-25 could only oxidize $83 \%$, 74\%, $80 \%$ of As(III) (Majumder et al., 2013); Klebsiella pneumoniae and Klebsiella variicola could only oxidize $87 \%$ and $83 \%$ of As(III) after $72 \mathrm{hr}$ (Butt and Rehman, 2011); it took $48 \mathrm{hr}$ for Pseudomonas arsenicoxydans sp. to finish oxidizing As(III) $(0.138 \mu \mathrm{mol} /(\mathrm{L} \cdot \mathrm{hr}))$ (Campos et al., 2010). In this study, strain HN-2 oxidized $61.4 \mu \mathrm{mol} / \mathrm{L}$ (92.0\%) of As(III) to As(V) $(20.47 \mu \mathrm{mol} /(\mathrm{L} \cdot \mathrm{hr}))$ with initial cell density of $10^{7} \mathrm{CFU} / \mathrm{mL}$ within $3 \mathrm{hr}$.

Microbial oxidation of As(III) occurs over a wide range of $\mathrm{pH}$. Some As(III)-oxidizing bacteria are able to oxidize As(III) at low $\mathrm{pH}(\leq 4)$, e.g., Sulfolobus acidocaldarius (Sehlin and Lindstrom, 1992) and Thiomonas arsenivorans (Dastidar and Wang, 2009). An autotrophic As(III)-oxidizing population (CASO1) was isolated that exhibited As(III) oxidation activity between $\mathrm{pH} 3-$ 8 (Battaglia-Brunet et al., 2002). However, most of the known As(III)-oxidizing bacteria demonstrated optimum oxidation at near-neutral $\mathrm{pH}$. The $\mathrm{pH}$ for growth of strain $\mathrm{HN}-2$ ranged from 6 to 9, while the optimum was 7. Bahar et al. (2012) reported that the optimum $\mathrm{pH}$ for As(III) oxidation was 5-7 for Stenotrophomonas sp. MM-7 and 6-8 for Variovorax sp. MM-1. Thus, $\mathrm{pH}$ modification is important for different cultures to maximize As(III) oxidation in the bioremediation of As(III). The ability of HN-2 to oxidize As(III) over a wide range of $\mathrm{pH}$ reveals its potential in remediation of As-contaminated water and soil.

The reduction rate for heterotrophic $\mathrm{As}(\mathrm{V})$ reduction by different strains varies considerably. Previous studies showed that the As(V)-reducing bacterium, Citrobacter sp. AR-7, almost completely reduced $\mathrm{As}(\mathrm{V})$ to As(III) with $3 \mathrm{hr}$ incubation (833.33 $\mu \mathrm{mol} /(\mathrm{L} \cdot \mathrm{hr})$ ) (Liao et al., 2011), Bacillus sp. SXB reduced $95 \% \mathrm{As}(\mathrm{V})$ of $1 \mathrm{mmol} / \mathrm{L}$ in $22 \mathrm{hr}(43.18 \mu \mathrm{mol} /(\mathrm{L} \cdot \mathrm{hr}))$, and Pantoea sp. IMH reduced 97\% As(V) of $1 \mathrm{mmol} / \mathrm{L}$ in $60 \mathrm{hr}$ (16.17 $\mu \mathrm{mol} /(\mathrm{L} \cdot \mathrm{hr})$ ) (Wu et al., 2013). Some isolated strains reduced As relatively slowly. Agrobacterium tumefaciens, Flavobacterium sp., Microbacterium sp. and Arthrobacter sp. were As(V) reducing bacteria isolated in aerobic conditions. Rates of $\mathrm{As}(\mathrm{V})$ reduction by those strains ranged from 0.5 to $3.3 \mu \mathrm{mol} /\left(\mathrm{L} \cdot\right.$ day) per $10^{9}$ cells

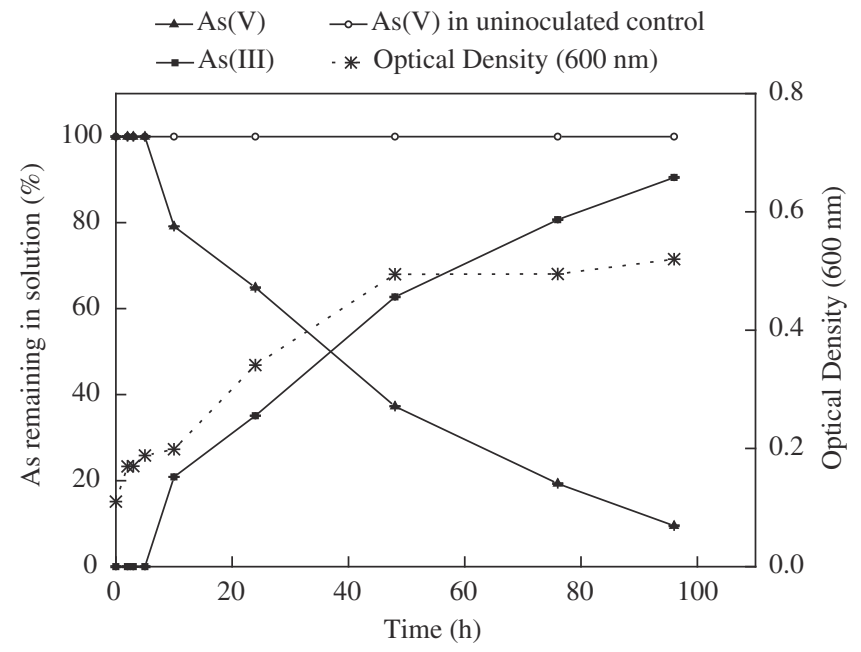

Fig. 4 - Growth (expressed as $\mathrm{OD}_{600}$ ) and $\mathrm{As}(\mathrm{V})$ reduction by strain $\mathrm{HN}-2$ in CDM containing $5 \mathrm{mg} / \mathrm{L} \mathrm{As}(\mathrm{V})$.

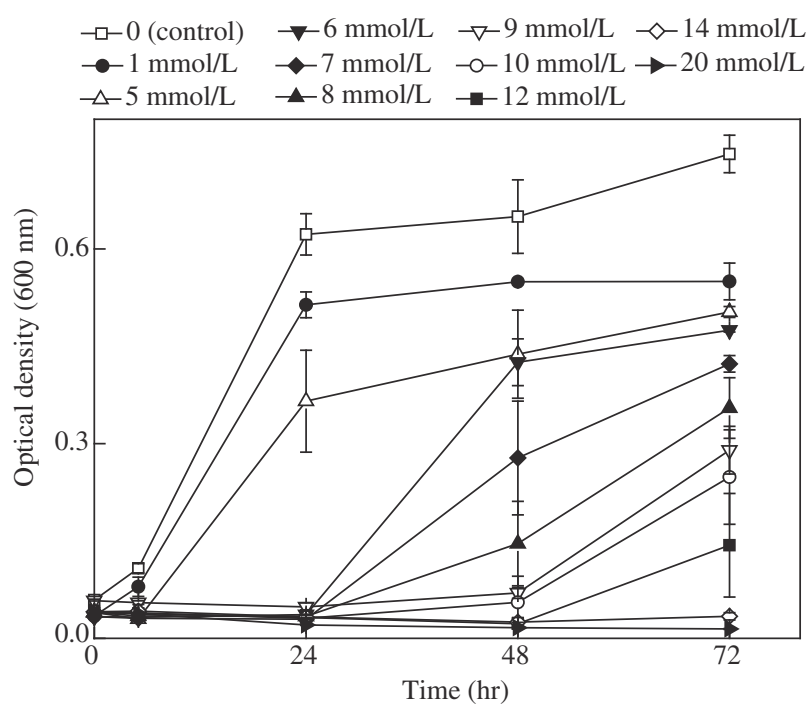

Fig. 5 - Growth curves of strain $\mathrm{HN}-2$ exposed to different concentrations of As(III) in CDM. 
(Macur et al., 2004). In our study, the reduction rate for $\mathrm{HN}-2$ was $0.66 \mu \mathrm{mol} /(\mathrm{L} \cdot \mathrm{hr})$ with initial cell density of $10^{7} \mathrm{CFU} / \mathrm{mL}$.

To date, all known aerobic arsenite oxidases exhibit a heterodimeric structure with molybdopterin (Mo-pterin) and Rieske-like subunits (Inskeep et al., 2007). The large subunit (AroA $\sim 90 \mathrm{kDa}$ ) of the arsenite oxidase is the first example of a new subgroup of the dimethylsulfoxide (DMSO) reductase family of molybdoenzymes (Ellis et al., 2001). It is reported that this heterodimeric enzyme is located on the outer surface of the inner membrane, and is transported to the cytoplasmic membrane (Lebrun et al., 2003). The arsenite oxidase gene has been used as genetic marker of $\mathrm{As}$ (III) oxidation (Hamamura et al., 2009). The large subunits of the arsenite oxidase gene of strain HN-2 were identified by PCR amplification using degenerate primers. The PCR products were later sequenced and confirmed as a part of the aroA gene. No oxidation was observed in the sterile controls, which indicated that As transformation required the presence of microbial cells. In addition, the strain could not grow in media designed for chemolithotrophic metabolism using As(III) as the sole electron donor. With the result that As(III) oxidation corresponded with microbial growth (Fig. 3), it is suggested that the mechanism of As(III) oxidation by the isolate was related to As detoxification rather than energy generation. Heterotrophic metabolic conversion of As(III) to $\mathrm{As}(\mathrm{V})$ is considered an As tolerance strategy, as $\mathrm{As}(\mathrm{V})$ is generally less toxic than As(III) (Cervantes et al., 1994; Cullen and Reimer, 1989).

Likewise, strain HN-2 could not grow in media designed for dissimilatory $\mathrm{As}(\mathrm{V})$ reduction, in which lactate served as the primary carbon and energy source and $\mathrm{As}(\mathrm{V})$ as the primary electron acceptor. This result was reasonable since the isolated organism was enriched under aerobic conditions. Thus, the reduction of $\mathrm{As}(\mathrm{V})$ by the isolated strain was also for detoxification purposes. Although growth studies confirmed the strain as an $\mathrm{As}(\mathrm{V})$-reducing bacteria, amplification of the arsC arsenate reductase gene was not successful using a range of primers and PCR conditions. This result may suggest a significant degree of novelty in the genes encoding enzymatic $\mathrm{As}(\mathrm{V})$ reduction in HN-2. Several studies observed that despite clear evidence of As-transforming activity by microorganisms, no amplicon for arsenite oxidase (aoxB), $\mathrm{As}(\mathrm{V})$ respiratory reductase (arr $\mathrm{A})$ or arsenate reductase ( $\operatorname{ars} C$ ) was attained using the reported PCR primers and protocols (Handley et al., 2009; Liao et al., 2011). Liao et al. isolated three arsenate-reducing strains of Pseudomonas, and PCR failed to amplify any As marker genes for the two Pseudomonas sp. strains AR-2 and AR-3. Several studies also showed that no ars gene was found in Pseudomonas sp.(Cai et al., 1998; Chang et al., 2007), suggesting that the ars operon is not always the same, even though the strains are categorized into the same genera. Therefore, this type of diversity should be considered when ars systems are examined using PCR-based techniques.

The MIC of As(III) for strain HN-2 lies between 12 and $14 \mathrm{mmol} / \mathrm{L}$. Bacterial tolerance to metal can be higher in complex organic growth media due to the reduced availability of metal ions that are chelated by organic ligands, when compared to the values found in minimum medium (Weeger et al., 1999). Therefore, the values could be higher in real soil environments. The As(III) tolerance level of $\mathrm{HN}-2$ is significantly higher than the previously reported arsenic-tolerant Pseudomonas sp.
(2-2.5 mmol/L) (Liao et al., 2011) and P. arsenicoxydans VC-1 (5 mmol/L) (Campos et al., 2010).

In our study, the DO, ORP and $\mathrm{pH}$ of the samples at different time intervals were monitored. Conditions within the culture were altered from aerobic to anoxic during the experiments. The change of $\mathrm{pH}$ from 7 to 8 has little effect on As transformation (Jing et al., 2008). Results indicated that the isolated strain behaved differently at different levels of DO, while $\mathrm{pH}$ and ORP kept relatively steady. It was reported by Liao et al. (2011) that an isolated As-resistant bacteria showed different As tolerance and that As(V)-reducing bacteria showed different $\mathrm{As}(\mathrm{V})$ reduction rates under aerobic and anoxic conditions. Thus, it is possible that bacteria behave distinctly at different DO because of diverse metabolic mechanisms in different growth conditions.

This study provides the first example of a soil As(III)oxidizing and $\mathrm{As}(\mathrm{V})$-reducing bacterium, and illustrates the potential impact on arsenic redox cycling within soil. Based on the results, Pseudomonas sp. HN-2 has the potential to impact arsenic mobility in both anoxic and aerobic environments. Under anoxic conditions, strain HN-2 may promote arsenic mobilization, as seen with other $\mathrm{As}(\mathrm{V})$-reducing microorganisms. However, if conditions favor the formation of arsenic sulfides, $\mathrm{As}(\mathrm{V})$ reduction may lead to arsenic immobilization (Gihring and Banfield, 2001). In aerobic conditions, by rapid conversion of As(III) to a more readily adsorbed species, As(III) oxidation may result in diminished transport of As.

For the As remediation process in the environment, the best approach to remove $\mathrm{As}(\mathrm{III})$ is to oxidize it into $\mathrm{As}(\mathrm{V})$ first, which is less soluble and much easier to remove. The isolated strain, with oxidizing ability over a range of $\mathrm{pH}$, has potential application in As remediation processes.

Due to the ability of strain HN-2 to grow under a variety of conditions and environments while reducing or oxidizing As, further studies are necessary to explore the impact of this organism on As cycling in nature.

\section{Conclusions}

Pseudomonas sp. HN-2 isolated from an As-contaminated soil was found to contain an arsenite oxidase gene catalyzing oxidation of $\mathrm{As}(\mathrm{III})$ to $\mathrm{As}(\mathrm{V})$. Optimum growth of the strain occurred at $\mathrm{pH}$ ranging from 6 to 9 . The oxidation of As(III) to As(V) was $92.0 \%(61.4 \mu \mathrm{mol} / \mathrm{L})$ within $3 \mathrm{hr}$ of incubation. Reduction of $\mathrm{As}(\mathrm{V})$ to $\mathrm{As}(\mathrm{III})$ occurred in anoxic conditions. Our study provides the first example of a soil As(III)-oxidizing and $\mathrm{As}(\mathrm{V})$-reducing bacterium, and illustrates the potential impact on arsenic redox cycling within soil. Therefore, strain $\mathrm{HN}-2$ has the potential to impact arsenic mobility in both anoxic and aerobic environments, and has potential application in As remediation processes.

\section{Acknowledgments}

This work was supported by the National Natural Science Foundation of China (No. 41571451) and the Special Funds for Science and Education Fusion of University of Chinese 
Academy of Sciences. We thank Yue Li for her effort in proofreading this article.

\section{R E F E R E N C E S}

Anderson, C.R., Cook, G.M., 2004. Isolation and characterization of arsenate-reducing bacteria from arsenic-contaminated sites in New Zealand. Curr. Microbiol. 48 (5), 341-347.

Bachate, S.P., Cavalca, L., Andreoni, V., 2009. Arsenic-resistant bacteria isolated from agricultural soils of Bangladesh and characterization of arsenate-reducing strains. J. Appl. Microbiol. 107 (1), 145-156.

Bachate, S.P., Nandre, V.S., Ghatpande, N.S., Kodam, K.M., 2013. Simultaneous reduction of $\mathrm{Cr}$ (VI) and oxidation of As(III) by Bacillus firmus TE7 isolated from tannery effluent. Chemosphere 90 (8), 2273-2278.

Bahar, M.M., Megharaj, M., Naidu, R., 2012. Arsenic bioremediation potential of a new arsenite-oxidizing bacterium Stenotrophomonas sp. MM-7 isolated from soil. Biodegradation 23 (6), 1-10.

Battaglia-Brunet, F., Dictor, M.C., Garrido, F., Crouzet, C., Morin, D., Dekeyser, K., et al., 2002. An arsenic(III)-oxidizing bacterial population: Selection, characterization, and performance in reactors. J. Appl. Microbiol. 93 (4), 656-667.

Bruneel, O., Personne, J.C., Casiot, C., Leblanc, M., Elbaz-Poulichet, F., Mahler, B.J., et al., 2003. Mediation of arsenic oxidation by Thiomonas sp in acid-mine drainage (Carnoules, France). J. Appl. Microbiol. 95 (3), 492-499.

Butt, A.S., Rehman, A., 2011. Isolation of arsenite-oxidizing bacteria from industrial effluents and their potential use in wastewater treatment. World J. Microbiol. Biotechnol. 27 (10), 2435-2441.

Cai, J., Salmon, K., DuBow, M.S., 1998. A chromosomal ars operon homologue of Pseudomonas aeruginosa confers increased resistance to arsenic and antimony in Escherichia coli. Microbiology 144 (10), 2705-2713.

Campos, V.L., Valenzuela, C., Yarza, P., Kaempfer, P., Vidal, R., Zaror, C., et al., 2010. Pseudomonas arsenicoxydans sp nov., an arsenite-oxidizing strain isolated from the Atacama desert. Syst. Appl. Microbiol. 33 (4), 193-197.

Cavalca, L., Corsini, A., Bachate, S.P., Andreoni, V., 2013. Rhizosphere colonization and arsenic translocation in sunflower (Helianthus annuus L.) by arsenate reducing Alcaligenes sp strain Dhal-L. World J. Microbiol. Biotechnol. 29 (10), 1931-1940.

Cervantes, C., Ji, G.Y., Ramirez, J.L., Silver, S., 1994. Resistance to arsenic compounds in microorganisms. FEMS Microbiol. Rev. 15 (4), 355-367.

Chang, J., Yoon, I., Kim, K., 2007. Isolation and ars detoxification of arsenite-oxidizing bacteria from abandoned arsenic-contaminated mines. J. Microbiol. Biotechnol. 17 (5), 812-821.

Chang, J., Kim, Y., Kim, K., 2008. The ars genotype characterization of arsenic-resistant bacteria from arsenic-contaminated gold-silver mines in the Republic of Korea. Appl. Microbiol. Biotechnol. 80 (1), 155-165.

Chang, J., Yoon, I., Lee, J., Kim, K., An, J., Kim, K., 2010. Arsenic detoxification potential of aox genes in arsenite-oxidizing bacteria isolated from natural and constructed wetlands in the republic of Korea. Environ. Geochem. Health 32 (2), 95-105.

Cherry, J.A., Shaikh, A.U., Tallman, D.E., Nicholson, R.V., 1979. Arsenic species as an indicator of redox conditions in groundwater. J. Hydrol. 43 (1-4), 373-392.

Corsini, A., Cavalca, L., Crippa, L., Zaccheo, P., Andreoni, V., 2010. Impact of glucose on microbial community of a soil containing pyrite cinders: role of bacteria in arsenic mobilization under submerged condition. Soil Biol. Biochem. 42 (5), 699-707.
Cullen, W.R., Reimer, K.J., 1989. Arsenic speciation in the environment. Chem. Rev. 89 (4), 713-764.

Dastidar, A., Wang, Y., 2009. Arsenite oxidation by batch cultures of Thiomonas arsenivorans strain b6. J. Environ. Eng. ASCE 135 (8), 708-715.

Ellis, P.J., Conrads, T., Hille, R., Kuhn, P., 2001. Crystal structure of the $100 \mathrm{kDa}$ arsenite oxidase from Alcaligenes faecalis in two crystal forms at 1.64 angstrom and 2.03 angstrom. Structure 9 (2), 125-132.

Fisher, J.C., Hollibaugh, J.T., 2008. Selenate-dependent anaerobic arsenite oxidation by a bacterium from mono Lake, California. Appl. Environ. Microbiol. 74 (9), 2588-2594.

Gihring, T.M., Banfield, J.F., 2001. Arsenite oxidation and arsenate respiration by a new Thermus isolate. FEMS Microbiol. Lett. 204 (2), 335-340.

Gihring, T.M., Druschel, G.K., McCleskey, R.B., Hamers, R.J., Banfield, J.F., 2001. Rapid arsenite oxidation by Thermus aquaticus and Thermus thermophilus: Field and laboratory investigations. Environ. Sci. Technol. 35 (19), 3857-3862.

Goyer, R.A., Clarkson, T.W., 1996. Toxic effects of metals. In: Klaassen, C.D. (Ed.), Casarett \& Doull's toxicology. The basic science of poisons, fifth ed. McGraw-Hill Health Professions Division, pp. 811-867 (ISBN. 71054766).

Green, H., 1918. Description of a bacterium which oxidizes arsenite to arsenate, and of one which reduces arsenate to arsenite, isolated from a cattle-dipping tank. S. Afr. J. Sci. 14, 465-467.

Hamamura, N., Macur, R., Korf, S., Ackerman, G., Taylor, W., Kozubal, M., et al., 2009. Linking microbial oxidation of arsenic with detection and phylogenetic analysis of arsenite oxidase genes in diverse geothermal environments. Environ. Microbiol. 11 (2), 421-431.

Handley, K.M., Hery, M., Lloyd, J.R., 2009. Redox cycling of arsenic by the hydrothermal marine bacterium Marinobacter santoriniensis. Environ. Microbiol. 11 (6), 1601-1611.

Inskeep, W.P., Macur, R.E., Hamamura, N., Warelow, T.P., Ward, S.A., Santini, J.M., 2007. Detection, diversity and expression of aerobic bacterial arsenite oxidase genes. Environ. Microbiol. 9 (4), 934-943

Jing, C., Liu, S., Meng, X., 2008. Arsenic remobilization in water treatment adsorbents under reducing conditions: Part I. Incubation study. Sci. Total Environ. 389 (1), 188-194.

Jones, L.C., Lafferty, B.J., Sparks, D.L., 2012. Additive and competitive effects of bacteria and Mn oxides on arsenite oxidation kinetics. Environ. Sci. Technol. 46 (12), 6548-6555.

Kaltreider, R.C., Davis, A.M., Lariviere, J.P., Hamilton, J.W., 2001. Arsenic alters the function of the glucocorticoid receptor as a transcription factor. Environ. Health Perspect. 109 (3), 245.

Lane, D., 1991. 16S/23S rRNA sequencing. In: Goodfellow, E.S.a.M. (Ed.), Nucleic acid techniques in bacterial systematics. Wiley, West Sussex, England, pp. 115-175.

Lebrun, E., Brugna, M., Baymann, F., Muller, D., Lievremont, D., Lett, M.C., et al., 2003. Arsenite oxidase, an ancient bioenergetic enzyme. Mol. Biol. Evol. 20 (5), 686-693.

Liao, V.H., Chu, Y., Su, Y., Hsiao, S., Wei, C., Liu, C., et al., 2011. Arsenite-oxidizing and arsenate-reducing bacteria associated with arsenic-rich groundwater in Taiwan. J. Contam. Hydrol. 123 (1-2), 20-29.

Liu, S.X., Athar, M., Lippai, I., Waldren, C., Hei, T.K., 2001. Induction of oxyradicals by arsenic: implication for mechanism of genotoxicity. Proc. Natl. Acad. Sci. 98 (4), 1643-1648.

Macur, R.E., Jackson, C.R., Botero, L.M., McDermott, T.R., Inskeep, W.P., 2004. Bacterial populations associated with the oxidation and reduction of arsenic in an unsaturated soil. Environ. Sci. Technol. 38 (1), 104-111.

Macy, J.M., Santini, J.M., Pauling, B.V., O'Neill, A.H., Sly, L.I., 2000. Two new arsenate/sulfate-reducing bacteria: mechanisms of arsenate reduction. Arch. Microbiol. 173 (1), 49-57. 
Majumder, A., Bhattacharyya, K., Bhattacharyya, S., Kole, S., 2013. Arsenic-tolerant, arsenite-oxidising bacterial strains in the contaminated soils of West Bengal, India. Sci. Total Environ. 463, 1006-1014.

Mokashi, S.A., Paknikar, K.M., 2002. Arsenic (III) oxidizing Microbacterium lacticum and its use in the treatment of arsenic contaminated groundwater. Lett. Appl. Microbiol. 34 (4), 258-262.

Muller, D., Lièvremont, D., Simeonova, D.D., Hubert, J.C., Lett, M.C., 2003. Arsenite oxidase aox genes from a metal-resistant $\beta$-proteobacterium. J. Bacteriol. 185 (1), 135-141.

Oremland, R.S., Stolz, J.F., 2003. The ecology of arsenic. Science 300 (5621), 939-944.

Osborne, F.H., Ehrlich, H.L., 1976. Oxidation of arsenite by a soil isolate of Alcaligenes. J. Appl. Bacteriol. 41 (2), 295-305.

Osborne, T.H., Jamieson, H.E., Hudson-Edwards, K.A., Nordstrom, D.K., Walker, S.R., Ward, S.A., et al., 2010. Microbial oxidation of arsenite in a subarctic environment: Diversity of arsenite oxidase genes and identification of a psychrotolerant arsenite oxidiser. BMC Microbiol. 10.

Salmassi, T.M., Venkateswaren, K., Satomi, M., Nealson, K.H., Newman, D.K., Hering, J.G., 2002. Oxidation of arsenite by Agrobacterium albertimagni, AOL15, sp. nov., isolated from Hot Creek, California. Geomicrobiol J. 19 (1), 53-66.

Santini, J.M., Sly, L.I., Schnagl, R.D., Macy, J.M., 2000. A new chemolithoautotrophic arsenite-oxidizing bacterium isolated from a gold mine: Phylogenetic, physiological, and preliminary biochemical studies. Appl. Environ. Microbiol. 66 (1), 92-97.

Sehlin, H.M., Lindstrom, E.B., 1992. Oxidation and reduction of arsenic by Sulfolobus acidocaldarius strain BC. FEMS Microbiol. Lett. 93 (1), 87-92.

Shi, J., Tang, Z., Jin, Z., Chi, Q., He, B., Jiang, G., 2003. Determination of $\mathrm{As}(\mathrm{III})$ and $\mathrm{As}(\mathrm{V})$ in soils using sequential extraction combined with flow injection hydride generation atomic fluorescence detection. Anal. Chim. Acta 477 (1), 139-147.

Shivaji, S., Suresh, K., Chaturvedi, P., Dube, S., Sengupta, S., 2005. Bacillus arsenicus sp nov., an arsenic-resistant bacterium isolated from a sidente concretion in West Bengal, India. Int. J. Syst. Evol. Microbiol. 55, 1123-1127.
Sumi, D., Himeno, S., 2012. Role of arsenic (+3 oxidation state) Methyltransferase in arsenic metabolism and toxicity. Biol. Pharm. Bull. 35 (11), 1870-1875.

Sun, Y.M., Polishchuk, E.A., Radoja, U., Cullen, W.R., 2004. Identification and quantification of ars $C$ genes in environmental samples by using real-time PCR. J. Microbiol. Methods 58 (3), 335-349.

Sun, W., Alvarez, R.S., Field, J.A., 2010. The role of denitrification on arsenite oxidation and arsenic mobility in an anoxic sediment column model with activated alumina. Biotechnol. Bioeng. 107 (5), 786-794.

Tamura, K., Dudley, J., Nei, M., Kumar, S., 2007. MEGA4: Molecular evolutionary genetics analysis (MEGA) software version 4.0. Mol. Biol. Evol. 24 (8), 1596-1599.

Tsai, S., Singh, S., Chen, W., 2009. Arsenic metabolism by microbes in nature and the impact on arsenic remediation. Curr. Opin. Biotechnol. 20 (6), 659-667.

Valenzuela, C., Campos, V.L., Yanez, J., Zaror, C.A., Mondaca, M.A., 2009. Isolation of arsenite-oxidizing bacteria from arsenic-enriched sediments from Camarones River, Northern Chile. Bull. Environ. Contam. Toxicol. 82 (5), 593-596.

Wang, X., Rathinasabapathi, B., Oliveira, L.M.d., Guilherme, L.R.G., Ma, L.Q., 2012. Bacteria-mediated arsenic oxidation and reduction in the growth media of arsenic hyperaccumulator Pteris vittata. Environ. Sci. Technol. 46 (20), 11259-11266.

Weeger, W., Lievremont, D., Perret, M., Lagarde, F., Hubert, J.C., Leroy, M., et al., 1999. Oxidation of arsenite to arsenate by a bacterium isolated from an aquatic environment. Biometals 12 (2), 141-149.

Wu, Q., Du, J., Zhuang, G., Jing, C., 2013. Bacillus sp SXB and Pantoea sp IMH, aerobic As(V)-reducing bacteria isolated from arsenic-contaminated soil. J. Appl. Microbiol. 114 (3), 713-721.

Zhang, G., Qu, J., Liu, H., Liu, R., Li, G., 2007. Removal mechanism of As(III) by a novel Fe-Mn binary oxide adsorbent: Oxidation and sorption. Environ. Sci. Technol. 41 (13), 4613-4619. 